\title{
ASSOCIATION OF CADRE'S KNOWLEDGE WITH AGE, DURATION OF WORK, EDUCATION, AND EMPLOYMENT ON THE USE OF IPOSYANDU APPLICATION IN PASAWAHAN, PURWAKARTA, INDONESIA
}

\author{
Fedri Ruluwedrata Rinawan ${ }^{1}$, Pratiwi Kusumastuti ${ }^{2}$, Ariyati Mandiri ${ }^{3}$, Rima K. Dewi ${ }^{4}$ \\ ${ }^{1,3}$ Department of Public Health, Faculty of Medicine, Universitas Padjadjaran, Street.Eyckman No.38 Gd. \\ Rumah Sakit Pendidikan Lt. 4 Bandung - 40161, West Java, Indonesia. \\ ${ }^{1}$ Center for Health System Study and Health Workforce Education Innovation, Faculty of Medicine, \\ Universitas Padjadjaran, Street. Eyckman No. 38, Bandung 40161, West Java, Indonesia. \\ ${ }^{2,3}$ Midwifery Undergraduate Program, Faculty of Medicine, Universitas Padjadjaran, Street. Raya Bandung \\ Sumedang KM.21, Hegarmanah, Kecamatan Jatinangor - 45363, Kabupaten Sumedang, West Java, \\ Indonesia. \\ ${ }^{4}$ Emergency Room Obtetric and Gynecology, RSUD Kota Makassar, Jl. Perintis Kemerdekaan KM.14, \\ Makassar, South Sulawesi, Indonesia.
}

\begin{abstract}
Posyandu cadres are important people whose role in implementing posyandu, including registration, weighing, counseling, recording, and reporting. Currently, the cadre task in recording and reporting is still manual. Therefore, cadres must be supported by information technology to facilitate their work. iPosyandu application is an android-based that is integrated and functioned for cadres in managing data. The application has been implemented at posyandu to obtain data of infants, toddlers, and pregnant women. This study aimed to determine the cadre's knowledge on the use of iPosyandu application, and its association with age, duration of work, education, and employment. The research method used a cross-sectional approach. We used a purposive sampling technique. The sample size was 82 cadres in 6 villages in Pasawahan subdistrict. Data collection was carried using a questionnaire. Spearman correlation and Chi-square were used to identify the associations. The results were all cadres had good knowledge and not associated with age, duration of work, education, and employment. This can be caused by the experience and implementation of the iPosyandu application during the last year. Other reasons were also identified, such as easy access to media information, and the learning time. Good knowledge of cadres in using the application needs to be maintained. Henceforth, further complementary research is needed to strengthen the knowledge by observing their skill under the umbrella of action research.
\end{abstract}

Keywords: Cadre, iPosyandu application, Implementation, Knowledge

\begin{abstract}
ABSTRAK
Kader posyandu adalah orang yang berperan penting dalam pelaksanaan posyandu, diantaranya dalam hal pendaftaran, penimbangan, konseling, dan pencatatan serta pelaporan. Tugas kader meliputi pencatatan dan pelaporan masih dilakukan secara manual. Oleh karena itu, kader harus didukung teknologi informasi untuk memudahkan pengerjaan tugasnya. Aplikasi iPosyandu merupakan aplikasi mobile berbasis android yang berfungsi untuk kader mangolah data. Data yang didapat di Posyandu mencakup data bayi, balita, dan ibu hamil. Penelitian ini bertujuan mengetahui pengetahuan kader terhadap penggunaan aplikasi iPosyandu termasuk hubunganya dengan umur, lama kerja, pendidikan, dan pekerjaan. Metode penelitian dengan pendekatan cross-sectional menggunakan teknik purposive sampling. Sampel dalam penelitian yakni 82 kader dari 6 desa yang berada di Kecamatan Pasawahan. Pengumpulan data dengan menggunakan kuesioner. Spearman correlation dan Chi-square digunakan untuk mengetahui hubungan. Pada penelitian ini diperoleh semua kader memiliki pengetahuan baik dan tidak berhubungan dengan umur, lama kerja, pendidikan, dan pekerjaan. Hal ini dapat disebabkan oleh pengalaman dan penerapan aplikasi selama satu tahun ke belakang. Hal lain yang dapat diidentifikasi adalah kemudahan mengakses media, dan waktu yang dimiliki kader dalam mempelajari aplikasi. Pengetahuan kader yang baik dalam penggunaan aplikasi iPosyandu perlu dipertahankan. Maka dari itu, penelitian lanjut diperlukan untuk memperkuat pengetahuan dengan mengobservasi keterampilan kader dalam payung action research.
\end{abstract}

Kata Kunci : Kader, Aplikasi iPosyandu, Implementasi, Pengetahuan

\footnotetext{
${ }^{1}$ Correspondece Address: Fedri Ruluwedrata Rinawan Department of Public Health, Faculty of Medicine, Universitas Padjadjaran, Street.Eyckman No.38 Gd. Rumah Sakit Pendidikan Lt.4 Bandung-40161,West Java, Indonesia. Email: f.rinawan@unpad.ac.id
} 


\section{Introduction}

The non-digital Posyandu Information System (PIS) is a previous register that is manually used for recording and reporting. The system is adjusted using a standard form based on government health programs. The recording is done immediately after the Posyandu activities are completed. ${ }^{1}$ Based on the Posyandu Cadre Training Manual, SIP is a system for managing information from Posyandu activities. SIP consists of 6 (six) forms, namely records of pregnant women and childbirth, pregnant women registers, baby registers, toddler registers, child-bearing age woman and couples registers, and data on Posyandu activities. ${ }^{2}$ However, we found the gap that the entire recording process is still done manually. Thus, errors often occur in the data input and reporting process. Innovation is needed to bridge the gap. ${ }^{3}$ Posyandu that uses manual data recording, and recapitulation systems result in data missing. The manually recording can make the public health center (Puskesmas), data back-up not systematic, resulting in inefficient recording time. ${ }^{4}$ It can affect the results of the data recapitulation.

In the era of digitizing, the operating system for smartphone devices is moving and developing. Smartphones can run software or applications that have their respective functions and continuity to grow. Mobile applications are widely used for helping activities in everyday life. The advantages of mobile application are easy and can be used anywhere. This application is suitable for helping activities that have high mobility. 5,6

The are $32 \%$ of health and maternal cadres in 2016 at the Posyandu of Pasawahan subdistrict, Purwakarta District, can operate a smartphone. This utilization was a potential initiation of the use of android-based technology. Besides, the existing Posyandu in the sub-district is mainly already independent to run Posyandu with more data coverage. When collecting the data, it often appears that the posyandu data is incomplete and missing. This causes the delay time of the data input process. Therefore, to simplify the process of recording and reporting posyandu, the 2017 Unpad Lecturer Competency Research (RKDU) made the innovation bridge in the form of a smartphone application prototype named iPosyandu.

Initially, iPosyandu app is created by Universitas Padjadjaran (Unpad) collaborating with posyandu, public health center (puskesmas), and district health office in Purwakarta. From 2019 until now, a private sector (PT. Astra International Tbk) supported the app development and scaleup the implementation to Posyandu fostered by Astra in Indonesia. iPosyandu app is an Androidbased mobile application that is functioned to manage data that has been obtained at Posyandu. The data includes similar to SIP, such as infants, toddlers, and pregnant women. It has been made more practical in terms of data management and processing with the aim of reducing data input and 
report problems. Cadre's knowledge in the effort of using the application is very important to overcome the existing problems. ${ }^{3,7,8}$

In 2018, the iPosyandu application was taught to cadres in Pasawahan sub-district with training interventions and the provision of user manuals for the application. ${ }^{8}$ In 2019, the description of knowledge was needed during the real implementation of posyandu. In this research, the implementation phase is carried out as an evaluation of the iPosyandu application. Cadre knowledge in the use of applications is very important in efforts to overcome existing problems; thus it must be further investigated ${ }^{9}$, including its association with age ${ }^{10,11}$, duration of work ${ }^{12,13}$, education ${ }^{14}$, and employment ${ }^{15,16}$. This study aimed to determine the cadre's knowledge on the use of iPosyandu application, and its association with age, duration of work, education, and employment.

\section{Method}

This research used a cross-sectional approach. ${ }^{17}$ It was part of a bigger umbrella of action research. Sustainability of the action research was needed for the application development in accordance with the user needs. The target population in this study includes all cadres posyandu located in Pasawahan Sub-district. From the above population, we chose all active Posyandu cadres, which numbered 82 people. The sampling technique in this study was using purposive sampling that matches the inclusion criteria (active cadres, aged 25-50 years, able to operate a smartphone, and have attended training using iPosyandu guideline book) consisting of cadres from 6 villages in the area including Cihuni, Kerta Jaya, Lebak Anyar, Pasawahan Kidul, Pasawahan, and Sawah Kulon. This research has an ethical number 337/UN6.KEP/EC/2019. The umbrella of the action research covers 12 villages in the sub-district with continuing exploratory sequential mixed-method design. We took only part of the research using cross-sectional approach in six villages to describe and identify the association of iPosyandu cadre's knowledge with age, duration of work, education, and employment.

In this study, the research instrument used a questionnaire comprising 25 statements. It included account management, benefits of the iPosyandu application, data on pregnant women, results of an examination of pregnant women, data on infants and toddlers, results of examinations of infants and toddlers, and digital Posyandu Information System (PIS). This instrument was already used by the previous study. ${ }^{8}$ We trained cadres as facilitators who educate other cadres regarding the iPosyandu implementation at their posyandu. They also had a role as enumerators of the research not at their posyandu but at other posyandu. The questionnaire was given just before the posyandu activities. Spearman correlation was used to identify knowledge's association with age and duration of work (numerical data, not normal distribution). Then, we tried using Multiple regression. Chi-square was used to know knowledge's association with education and employment 
(categorical data). Afterward, we calculated the odds ratio (OR). The data analyses were processed using STATA 15.1 Special Edition program (licensed from StataCorp 4905 Lakeway Drive College Station, Texas 77845 USA).

\section{Results}

Table 1. Characteristics of Respondents

\begin{tabular}{lcc}
\hline \multicolumn{1}{c}{ Characteristics of Respondents } & Frequency (n) & Percentage (\%) \\
\hline Age (years) & 16 & 19.51 \\
$26-35$ & 32 & 39.03 \\
$36-45$ & 34 & 41.46 \\
$46-50$ & & \\
Education & 21 & 25.61 \\
$\quad$ Elementary school & 31 & 37.80 \\
Junior High School & 29 & 35.37 \\
$\quad$ Senior High school & 1 & 1.22 \\
University & 2 & 2.44 \\
Employment & 80 & 97.56 \\
$\quad$ Private employee & & \\
$\quad$ Housewife & 20 & 24.39 \\
The duration of being a cadre & 62 & $\mathbf{7 5 . 6 1}$ \\
$\quad \leq 3$ years & $\mathbf{8 2}$ & $\mathbf{1 0 0}$ \\
$\quad$ 3 years & & \\
\hline Total & & \\
\hline
\end{tabular}

From Table 1, it can be seen that the characteristics of respondents based on the age of the majority were $46-50$ years as many as 34 people $(41.46 \%)$. As for the level of education, middle school was the highest (37.80\%). Based on job characteristics, almost all did not work $(97.56 \%)$. Looking at the length of time being a cadre, most of them had a work period of $>3$ years $(75.61 \%)$. In the field, all of the cadres involved in the study used the iPosyandu app during the posyandu activities from 8 to $11 \mathrm{AM}$.

Table 2. Knowledge's Association with Age and Duration of Work

\begin{tabular}{|c|c|c|c|c|}
\hline Variable & $n$ & Median (range) & $p$ value* & $p$ value** \\
\hline Knowledge & 82 & $92(80-100)$ & & \\
\hline - $\quad$ Age (year old) & & $44(26-50)$ & 0.28 & 0.98 \\
\hline - Duration of work (year) & & $7(1-29)$ & 0.86 & \\
\hline
\end{tabular}

$* p$ value Spearman correlation

**p value Multiple regression

Table 2 depicts the knowledge obtained by 82 respondents with minimum score of 80 , a maximum score of 100, and a median of 92. Each association using Spearman correlation or multiple regression resulted not significant $p$ value. Because the range of the knowledge was between 80 to 100 , we recorded the knowledge into $\geq 90$ and $<90$ for the correlation analysis with the other categorical data. 
Table 3. Knowledge's Association with Education

\begin{tabular}{|c|c|c|c|c|c|c|}
\hline \multirow{3}{*}{ Education } & \multicolumn{4}{|c|}{ Knowledge } & \multirow{3}{*}{$p$ value } & \multirow{3}{*}{ OR } \\
\hline & \multicolumn{2}{|c|}{$\geq 90$} & \multicolumn{2}{|c|}{$<90$} & & \\
\hline & $(\mathrm{n})$ & $(\%)$ & (n) & $(\%)$ & & \\
\hline Elementary and Junior High School & 29 & 59.18 & 23 & 69.70 & \multirow{2}{*}{0.33} & \multirow{2}{*}{0.63} \\
\hline Senior High school and University & 20 & 40.82 & 10 & 30.30 & & \\
\hline Total & 49 & 100.00 & 33 & 100.00 & & \\
\hline
\end{tabular}

Table 4. Knowledge's Association with Employment

\begin{tabular}{|c|c|c|c|c|c|c|}
\hline \multirow{3}{*}{ Employment } & \multicolumn{4}{|c|}{ Knowledge } & \multirow{3}{*}{$p$ value } & \multirow{3}{*}{ OR } \\
\hline & \multicolumn{2}{|c|}{$\geq 90$} & \multicolumn{2}{|c|}{$<90$} & & \\
\hline & (n) & $(\%)$ & (n) & $(\%)$ & & \\
\hline Housewife & 48 & 97.96 & 32 & 96.97 & \multirow{2}{*}{0.78} & \multirow{2}{*}{1.5} \\
\hline Private employee & 1 & 2.04 & 1 & 3.03 & & \\
\hline Total & 49 & 100.00 & 33 & 100.00 & & \\
\hline
\end{tabular}

Table 3 and 4 show that both education and employment of cadres had no association with their knowledge of using iPosyandu application. Almost all cadres were housewife. Despite no association, knowledge of cadres with elementary and junior high school background was 0.63 times cadres with senior high school and university background. 'Housewife' cadres' knowledge was 1.5 'private employee' cadre.

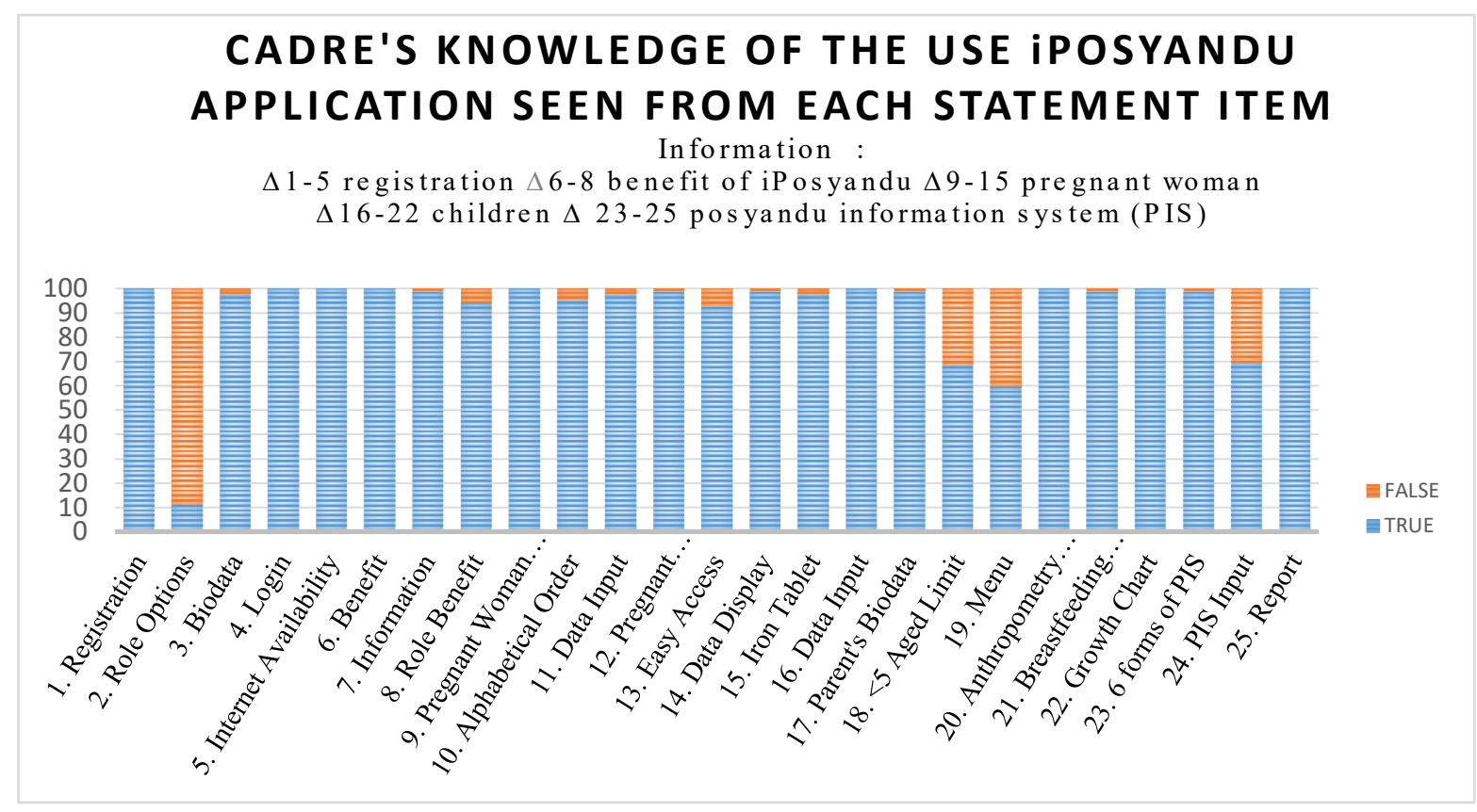

Figure 1. Cadre's Knowledge of the Use of the iPosyandu Application 2019

Looking at the figure 1 above, there are several statements that were answered incorrectly by respondents. Following are the most inaccurate statements, including:

Statement 2 "The option to register an iPosyandu account is available as a cadre and as a parent". 
The correct answer is "incorrect". As much as $89.02 \%$ of respondents answered incorrectly. This can be caused by previous studies where the use of the iPosyandu application was still on the same dashboard between cadres and parents. ${ }^{3}$

Statement 18 "Recording toddlers data on the iPosyandu application is carried out until children are older than 5 years".

The correct answer is "incorrect". The majority of respondents answered correctly at $68.31 \%$.

Statement 19 "Data of infants and toddlers are entered in the same menu as data of pregnant women".

The correct answer is "incorrect". More than half of respondents answered correctly that is $59.76 \%$.

Statement 24 "The PIS form is filled at the beginning and end of the year, not every month."

The correct answer is "incorrect". The majority of respondents answered correctly that is $69.51 \%$.

\section{Discussion}

Knowledge in using the iPosyandu application is everything that is absorbed by the cadres and can be obtained after learning the application. Most of human knowledge is gained through the ears and eyes. ${ }^{14} \mathrm{~A}$ person's knowledge is influenced by two factors comprising internal factors (education, experience, and age), and external factors (environmental, social, cultural, information, and media). ${ }^{17,18}$ Cadres who have good knowledge are those who answer correctly and appropriately on the use of the iPosyandu application during the implementation of Posyandu. This study shows the results of the prominent cadre's knowledge of the use of the iPosyandu application. All cadres have good knowledge with an average value of 91.02. This can be caused by training and the provision of manuals for the use of the iPosyandu application in 2018, as well as its use for one year. ${ }^{89}$ Knowledge about an object can be influenced by experience and information that has been obtained before. ${ }^{5}$ The training and experience of cadres using the iPosyandu application could increase knowledge, making it easier to use. ${ }^{8,19}$ In our research, repeated measurements of knowledge as part of the umbrella of action research is essential to see changes in knowledge after the application of the iPosyandu. During one year of the research umbrella, cadre's knowledge should corroborate with the development of applications that change dynamically according to the needs of cadres. ${ }^{3}$ Lack of knowledge in our study can be an indicator of the dynamic improvement. The support of the puskesmas and village office is essential for the improvement. Moreover, family support is crucial for cadre to run and maintain posyandu activities. We found role options, $<5$ aged limit, menu, and PIS input are the least knowledge that can be used for targeting more development to the cadres and 'what are not understood' on the app. We collect the gap or "pain point" and prevent bad impact by accommodating iterative action and reflection in the improvement. ${ }^{3,20}$ 
The age characteristics in this study vary from 26-50 years, which are categorized into early adulthood, late adulthood, and early elderly. As we get older, so the catching and mindset of a person also develop. In addition, the more information and things done forward in someone's age or timeline, the knowledge obtained is better. ${ }^{14}$ However, some conditions in someone's age can go inversely with someone's knowledge and experience. ${ }^{10}$ At a certain age or nearing old age, there will be a stage where the ability to receive or remember information will decrease. So that there is a decline in knowledge and memory deterioration. ${ }^{11}$

The characteristics of education in this study are spread in elementary, junior high, high school, and university. It can affect a person's learning process. The higher the level of education, the easier it is for someone to accept the information provided. ${ }^{14}$ In this study, although the main cadre's education is junior high, the knowledge is still in the good category. A majority of cadres have a service period of $>3$ years. A long working period can increase the cadre's knowledge because of the long learning process that can be done. ${ }^{12,13}$ However, for a new application they need to learn more. In terms of learning time, the majority of cadres were housewives. Thus, they have enough free time to learn and improve their knowledge. It is in line with other research that pointed out that study time had an effect on one's level of knowledge and skills. ${ }^{15,16}$

Mobile-based health (m-health) application is widely used and is growing rapidly in the globalization era. The arising impacts are quite diverse such as the ease of delivering information that can increase knowledge. ${ }^{6,21}$ The iPosyandu application serves to assist cadres in working on monthly and annual reporting to the government. It also holds information about the health of pregnant women, infants, and toddlers. ${ }^{8}$ The use of applications in daily activities can help someone more easily capturing and understanding information. Then, it can affect human knowledge because knowledge can be influenced by the use of m-health during the learning process. ${ }^{22,23}$ Mobile health technology is highly recommended as a means to bridge the knowledge gap. This technology can improve the performance of health workers. ${ }^{24,25}$ Barhoumi's research, in 2015 about the effectiveness of mobile learning using WhatsApp, influences the level of student knowledge. ${ }^{26}$ The use of application affects the mother's knowledge about child development and the management of physical activities carried out by her baby. ${ }^{27}$ Pratiwi's research, in 2018 stated that there was an influence of the android-based application "Status Gizi Balita" on the mother's knowledge in monitoring the nutritional status of children. ${ }^{28}$

Training on applications can increase understanding and knowledge about using mobile health, ${ }^{29}$; however, most research on mobile health only reaches the intervention or implementation stage. ${ }^{30}$ In our research, the implementation phase is carried out not only to find out the description of knowledge but also to explore the lack of application. These gaps provide input for further improvement in the future. Continuity of action research is essential to be carried out iteratively in 
stages and in the development of mobile health. This is very important so that it can provide benefits to the community in the long run. ${ }^{31,32}$

This research is limited to cadres who live in the area with bad connectivity. Further versions of iPosyandu application will be developed to cover this limitation.

\section{Conclusion}

Based on the results to the discussion above, cadres have different characteristics related to age, education, occupation, and the length of time to be a cadre. Cadre knowledge regarding the use of the iPosyandu application during posyandu implementation has a good category. This can be supported by experiences and training that have been received previously, the length of cadre's service, the information, and the more time that cadres have in learning iPosyandu application.

\section{Acknowledgement}

We would like to acknowledge Universitas Padjadjaran for supporting the research, Purwakarta District Government for scaling up iPosyandu app to puskesmas and posyandu in Pasawahan Sub-district, Indah Lavenina Gunawan for helping the data collection, and Kreasi Insani Persada Foundation for helping the research.

\section{Funding}

There is no funding for this research in 2019. The funds used the author's personal funds. However the umbrella of action research funding was initiated by Lecturer Competence Internal Grant of Universitas Padjadjaran, Indonesia in 2017-2018.

\section{Conflict of Interest}

There is no conflict of interest concerning this study, authorship, and the publication of this article.

\section{References}

1. Kementerian Kesehatan RI. Pedoman Umum Pengelolaan Posyandu. Jakarta : Kemenkes RI. 2011.

2. Kementerian Kesehatan RI. Buku Panduan Kader Posyandu Menuju Keluarga Sadar Gizi. Jakarta : Kemenkes RI. 2011.

3. Rinawan FR. Understanding Mobile Application Development and Implementation To Monitor Posyandu Data in Indonesia: a 3-years hybrid action research to build "a bridge" from the community to national use (underreview). 2020;DOI: 10.21203/rs.3.rs-15584/v2.

4. Sholihah N KS. Sistem Informasi Posyandu Kesehatan Ibu dan Anak. Prosiding SNATIF. 2015;207-14.

5. Kusumawardani LH, Jauhar M, Rasdiyanah R, Rohana IGAPD. Pojokbelia: The Study of Smart Phone Application Development as Communicative, Informative and Educative (KIE) Media Innovation for Adolescent Reproductive Health. Jurnal Keperawatan Soedirman. 2018;13(3):125-37. 
6. Silva BM, Rodrigues JJ, de la Torre Díez I, López-Coronado M, Saleem K. Mobile-health: A review of current state in 2015. Journal of biomedical informatics. 2015;56:265-72.

7. UNPAD. Buku Pedoman iPosyandu Untuk Kader. 2018.

8. Widarti W, Rinawan FR, Susanti AI, Fitri HN. Perbedaan Pengetahuan Kader Posyandu Sebelum dan Sesudah Dilakukan Pelatihan Penggunaan Aplikasi iPOSYANDU. Jurnal Pengabdian dan Pengembangan Masyarakat. 2018;1(2):143-50.

9. Susanti AI, Rinawan FR, Amelia I. Penggunaan Mobile Apps Kesehatan oleh Kader Pada Anjungan Mandiri Posyandu (AMP) Di Kecamatan Pasawahan, Purwakarta. Jurnal Kesehatan Vokasional. 2019;4(1).

10. Nujmatul LJKDFEU. Pengaruh Literasi Keungan Terhadap Perilaku Mahasiswa Dalam Mengelola Keuangan. 2016.

11. Koski L, Xie H, Finch LJJogp, neurology. Measuring cognition in a geriatric outpatient clinic: Rasch analysis of the Montreal Cognitive Assessment. 2009;22(3):151-60.

12. Pamungkas ADP, Hamid D, Prasetya AJJAB. Pengaruh Pendidikan dan Pengalaman Kerja Terhadap Kemampuan Kerja dan Kinerja Karyawan (Studi pada Karyawan PT. INKA (Persero)). 2017;43(1):96-103.

13. Hani H. Manajemen Sumber Daya Manusia. Yogyakarta: BPFE-Yogyakarta; 2008.

14. Notoatmodjo S. Promosi Kesehatan dan Perilaku Kesehatan. Jakarta : Rineka Cipta. 2012.

15. Lestari IJFJIPM. Pengaruh waktu belajar dan minat belajar terhadap hasil belajar matematika. 2015;3(2).

16. Sudarsana IKJJPM. Pengaruh Model Pembelajaran Kooperatif Terhadap Peningkatan Mutu Hasil Belajar Siswa. 2018;4(1):20-31.

17. Notoatmodjo S. Metodologi Penelitian Kesehatan. Jakarta : Rineka Cipta. 2018.

18. Krathwohl DR. A revision of Bloom's taxonomy: An overview. Theory into practice. 2002;41(4):212-8

19. Wawan A, Dewi MJYNM. Teori dan pengukuran pengetahuan, sikap dan perilaku manusia. 2010:11-8.

20. Ivankova N. WN. Applying Mixed Methods in Action Research: Mwthodological Potentials and Advatages. American Behavioral Scientis. 2018:978-97.

21. Shim JW. The use of e-health information and health behavior change: The role of perceived health status and types of e-health information use. Open Communication Journal. 2008;2:156-63.

22. WHO. mHealth New Horizons For Health Through Mobile Technologies. 2011.

23. Chan A, Kow R, Cheng JKJJoMTiM. Adolescents' perceptions on smartphone applications (apps) for health management. 2017;6(2):47-55.

24. Bollinger R, Chang L, Jafari R, O'Callaghan T, Ngatia P, Settle D, McKenzie-White J, Patel K, Dossal, and Al Shorbaji N. Leveraging information technology to bridge the health workforce gap. Bulletin of the World Health Organization. 2013;91:890-2.

25. Braun R, Catalani C, Wimbush J, Israelski D. Community health workers and mobile technology: a systematic review of the literature. PloS one. 2013;8(6):e65772.

26. Barhoumi CJCET. The Effectiveness of WhatsApp Mobile Learning Activities Guided by Activty Theory on Students' Knowldege Management. 2015;6(3):221-38.

27. Kamila NA, Susiarno H, Gurnida DA, Afriandi I, Garna H, Djuwantono T. Pengaruh penerapan aplikasi sayang ke buah hati (SEHATI) terhadap pengetahuan ibu dan aktivitas fisik pada anak sekolah dasar. 2017;5(2):132-9. 
28. Pratiwi IG, Restanti DAJJKAKJ. Penerapan Aplikasi Berbasis Android" Status Gizi Balita" terhadap Pengetahuan Ibu dalam Pemantauan Status Gizi Anak Usia 12-24 Tahun. 2018;2(1):8-14.

29. Agarwal S, Perry HB, Long LA, Labrique AB. Evidence on feasibility and effective use of $\mathrm{mH}$ ealth strategies by frontline health workers in developing countries: systematic review. Tropical medicine \& international health. 2015;20(8):1003-14.

30. Glick G, Druss B, Pina J, Lally C, Conde M. Use of mobile technology in a community mental health setting. Journal of telemedicine and telecare. 2016;22(7):430-5.

31. Sukums F, Mensah N, Mpembeni R, Massawe S, Duysburgh E, Williams A, Kaltschmidt J, Laukanova S, Haefeli WE, Blank A. Promising adoption of an electronic clinical decision support system for antenatal and intrapartum care in rural primary healthcare facilities in subSaharan Africa: The QUALMAT experience. 2015;84(9):647-57.

32. Kaphle S, Chaturvedi S, Chaudhuri I, Krishnan R, Lesh NJJm, uHealth. Adoption and usage of mHealth technology on quality and experience of care provided by frontline workers: observations from rural India. 2015;3(2):e61. 
